\title{
PROFESSIONAL ACADEMIC DEVELOPMENT - THE INFLUENCE OF CONTEXT ON MOTIVATION
}

\author{
B. L. Leibowitz \\ Faculty of Education \\ University of Johannesburg \\ Johannesburg, South Africa \\ e-mail: brendal@uj.ac.za
}

\section{ABSTRACT}

This study explores the relationship between intrinsic motivation, extrinsic motivation and contextual social and material conditions influencing the desire of academics to learn to teach at three South African universities. It considers these three influences from the perspective of selfdetermination theory, and argues that the theory is relevant for a discussion on motivation to learn to teach, but that the theory should be modified to take into account a more socio-political perspective. A careful analysis of these forms of intrinsic and extrinsic motivation in combination with contextual influences has implications for national and institutional policy on professional academic development. The study suggests that extrinsic forms of motivation may play an important role in encouraging academics to participate in professional development opportunities, but they are rendered less effective by sub-optimal social and material conditions, and thus by issues of social injustice and inequality. The study is based on interviews with 31 academics at three South African universities.

Keywords: professional development, professional learning, context, motivation, university teaching

\section{INTRODUCTION}

Initiatives to enhance teaching and learning at university level are based on inherent or speltout assumptions about learning, development or change. One set of assumptions concerns the role of motivation in learning to teach. National and institutional teaching excellence awards, promotion criteria acknowledging good teaching, or policy directives making participation in professional academic development schemes or programmes compulsory, rely especially on extrinsic, instrumental or externally-driven forms of motivation for their effectiveness. There has not been a concerted focus in research on professional academic development, which has explored the different forms of motivation and whether the dynamics informing motivation are similar across higher educational institutional contexts.

This study is an exploration into the dynamics informing motivation to learn in three diverse higher education institutional settings. The intended outcome is to suggest directions 
for further research on the role of motivation, and to make observations that might usefully inform strategies on enhancing learning and teaching at the national or institutional level in South Africa. The questions informing the study are:

1. Based on accounts of academics who are committed to enhancing their teaching across three South African university settings, what is the significance of motivation in participation in professional academic development opportunities?

2. How do various forms of motivation relate to one another?

3. How do these forms of motivation interact with contextual features in varied settings?

This study is based on a pragmatic approach, in that it is focused on the possible and practical consequences of the research, in this case, suggestions for policy or action (Creswell 2003) rather than on a particular philosophical framework that informs the research (Greene, Kreider and Mayer 2005). Further, in this approach, perception, valuation and interpretation are all considered important aspects of experience, which is the subject of inquiry in pragmatic research (Roziek 2013).

A useful lens to explore meanings associated with motivation is that of self-determination theory, in which authors Ryan and Deci (2000a; 2000b) have characterised motivation in great depth and over a number of studies. These concepts have been influential in approaches to teaching and learning.

\section{MOTIVATION}

Motivation is a psychological construct that has been applied to the learning of both children and adults. Self-determination theory, which has been influential in Western theories of education, concerns our attempts to achieve something, or 'to be moved to do something' (Ryan and Deci 2000b, 54). In organisational or teaching and learning contexts, it is crucial in engendering and sustaining change (Ryan and Deci 2000b, 76). Ryan and Deci distinguish between intrinsic motivation, where the rewards are inherent in the activity itself (for example, the challenge, joy or novelty of learning), resulting in quality learning and creativity (Ryan and Deci 2000b) and extrinsic motivation, where the rewards are external and often instrumental (for example, winning a prize or earning a better salary as the result of learning to teach). Conditions encouraging extrinsic motivation pose risks, in that, potentially, they lead to a lack of autonomy or drive to learn, as one is seeking instrumental rewards or one is learning out of compulsion rather than interest. In many contexts, such as the school or workplace, one cannot always rely on intrinsic motivation. Thus one needs to investigate forms of extrinsic motivation, 
which vary in terms of the degree of autonomy they induce (Ryan and Deci 2000b).

Ryan and Deci maintain that they are interested in the psychological needs which form the basis for self-motivation: competence, relatednesss and autonomy. They are also interested in the contextual conditions that foster or hinder motivation. In this study on professional academic development, the focus is on the influence of the institutional context on motivation to learn to teach. Self-determination theory (SDT) is a useful construct, as will be shown in relation to the findings of this study, but there are several areas of incompatibility with the proposed aims and focus of the present study. The first is in terms of research setting, since the findings of Ryan and Deci are mostly obtained in the laboratory or via experimental design, and to a lesser extent in the classroom. The present study concerns itself with adults learning in a natural environment and a social context. Ryan and Deci (2000b) indicate that some of the findings regarding motivation are obtained by self-reporting, which is, indeed, a mode relied upon in the present study. A second difference in emphasis is the lack of attention in SDT to matters of power, politics and equality. These points of difference do not militate against the use of the construct, but rather point to the need for it to be revised, if the theory is to be applied to professional academic development.

\section{PROFESSIONAL ACADEMIC DEVELOPMENT}

For the sake of intelligibility within the academic development discourse community, the term 'professional academic development' is used in this article. There have been numerous criticisms of the phrase 'professional development', as it suggests that academics have a knowledge or skills deficit that should be ameliorated by others (professional developers) (Webster-Wright 2009). An alternative term is 'professional learning', which suggests that academics are in control of their own learning (Knight, Tait and Yorke 2006). Professional learning suggests that learning occurs in a wide range of both formal processes (for example, workshops or academic programmes) as well as informal processes (via the tea-room, reading articles that one chooses, from engagement with students). However, as was argued in Leibowitz, Van Schalkwyk, Ruiters, Farmer and Adendorff (2012), there is a continuum between formal opportunities to learn to teach and informal opportunities to learn to teach. One also learns by constantly paying attention to cues from students, and by trial and error and by innovation in response to challenges in the learning situation. In all forms of learning, reflection is key (Kane, Sandretto and Heath 2004). For this reason, if one is motivated to teach well, one is possibly motivated to learn to teach, too, and thus factors influencing the motivation to teach well may also have an impact on motivation to learn to teach. For this reason, the study does not make a strong distinction between participation in formal development activities, informal 
activities and simply learning by teaching attentively and diligently. In this article, the term 'professional academic development' is used to refer to the formal processes, including policy and funding initiatives. The term 'learning to teach' refers to learning to teach in general, and to learning on the job.

\section{RESEARCH DESIGN AND SETTING}

This study is part of a collaborative, multi-site study investigating the influence of context on academics' engagement in professional academic development, for which data was collected at eight South African universities by academic developers at those institutions. This sub-study focuses on the motivation of academics to learn to teach, and for this reason the focus of this sub-study is on the interviews with 10-16 academics at three of the participating institutions. The academics were selected in order to represent a range of disciplines, levels of seniority, gender and ethnicity. For this article 31 interview transcripts were analysed. The academics were asked to be interviewed on the basis of their willingness to participate in an electronic survey, in which most indicated a strong enthusiasm for teaching. More information about the project and about its publications is available at http://interplayofstructure.blogspot.com.

For the broader study, a semi-structured interview schedule for the interviews with academics was devised in workshop mode by the research team. The interviews were conducted by members of the research team from each of the participating institutions. In the data set used for this sub-study at University One, interviews were conducted by four team members, at University Two by two team members and at University Three by one person who was not a team member but an academic developer at that institution. She was trained by a team member to conduct the interviews. This research thus constitutes a form of 'insider research in universities' (Trowler 2012) with all the attached benefits (such as understanding the terrain and being able to explore silences and gaps) and risks (for example, the interviewee not wanting to hurt the feelings of the interviewer). All the data for the over-arching study were collected between 2011 and 2012. The picture that might emerge from the data is time-bound, and does not represent conditions in those settings at the time this article is published.

University One was an urban, highly resourced university (in the South African context), located in a prosperous town, and it considered itself 'research-oriented'. At the time of the interviews it had a well-established, medium-sized teaching and learning centre that operated centrally. In the reflective report prepared by researchers at University One, which accompanied the interviews, the writers maintained that there was a severe imbalance of focus at the university, with incentives for research rather than for teaching. Participation in professional development was not overtly encouraged and it was not built into the appointment 
and promotion system. There were many opportunities for professional development, but no formal academic professional development programme.

University Two was an urban university that was not well resourced, in an industrial periurban setting, and did not consider itself 'research-oriented'. As a recent intervention it had one senior staff member responsible for academic development, a policy-and-committees approach to academic development, with the bulk of the academic development work occurring in the faculties. Participation in professional development was overtly encouraged but it was not built into the appointment and promotion system. There were many opportunities for professional development, but no formal academic professional development programme.

University Three was a rural institution in a context of poverty. It was under-resourced and the result of a merger of three sets of campuses. It did not consider itself research oriented and it had a well-established and centralised teaching and learning centre. Professional academic development was embedded in policy, a short course on assessment was compulsory and a postgraduate diploma in teaching and learning was on hand at the university.

For this study the interview transcripts were analysed by one person (the author of this article) according to the themes of intrinsic motivation, extrinsic motivation and environmental or contextual features. Within these categories, further content-related coding was undertaken. Instances of particular content items were counted where appropriate to gain a sense of their prominence.

\section{FINDINGS}

\section{Intrinsic motivation}

Table 1: Forms of intrinsic motivation per institution

\begin{tabular}{|l|l|l|}
\hline \multicolumn{2}{|c|}{ Forms of intrinsic motivation } \\
\hline & $\begin{array}{l}\text { Enjoyment, intellectual fulfilment } \\
\text { according to number of academics } \\
\text { who mentioned this }\end{array}$ & $\begin{array}{l}\text { Belief in the social good value of teaching } \\
\text { according to number of academics who } \\
\text { mentioned this }\end{array}$ \\
\hline $\begin{array}{l}\text { University One } \\
11 \text { interviewed }\end{array}$ & 5 & 6 \\
\hline $\begin{array}{l}\text { University Two } \\
10 \text { interviewed }\end{array}$ & 7 & 5 \\
\hline $\begin{array}{l}\text { University Three } \\
10 \text { interviewed }\end{array}$ & 10 & 7 \\
\hline
\end{tabular}

Intrinsic motivation informed academics' desire to teach as well as their desire to learn to teach.

Care for their students' learning was a strong motivator for academics to learn to teach:

I wanted to involve the students in the learning but I wasn't sure how I would do that. So at times I would go into the lectures of the senior members of staff and sit in there. So that really assisted 
me, seeing how they interact with the students, how they allowed students to participate in their lectures. (Lecturer 1, University Two)

Intrinsic motivation was also linked to enjoyment of teaching or of interacting with students. Many academics referred to teaching as a 'passion', saying they 'love' or 'enjoy' it:

I'm very comfortable when I'm in class, that's my happiest moment. In fact, I will include supervision and all of that as part of teaching. ... That is really my peak moment, when I'm interacting with students, or, indeed, with an audience. I'm probably trying to converse with, or impart knowledge, or learn - those are my moments. (Lecturer 10, University Three)

Explanations of enjoyment ranged from the interpersonal, as in the above quote - to the more intellectual, where academics stressed how much they learnt from teaching. They learnt from the students about students' views and behaviour and about ways to innovate and do things differently.

A further form of intrinsic motivation was a sense of the value of teaching and its ability to impact positively on the lives of students, on their broader communities or on the planet. An academic at University One explained how his concern with sustainability and finance informed his passion for teaching:

[Teaching is] really a passion and I can see there's a great need for it. ... it's definitely a calling. There's a great multiplier effect in teaching. ... I started doing research in environmental finance, which is your carbon trading, that kind of stuff. ... there's a great multiplier effect in teaching. When you teach people you sort of, you spread the message, and those people go tell. And if you good ... do that well enough, I think that effect is much bigger. (Lecturer 3, University One)

At University Two a lecturer shared her hope that her students would become critical, ethical and transformative professionals, and in this way, would contribute to the betterment of society:

I guess I realised more and more that teaching is really what gives me a buzz. You know, I've had a chance in management, admin and stuff, and teaching gives me a real buzz. ... teaching is transformative and really making an impact on students' lives, particularly at first-year level ... I've always tried to think about producing scientists, but different kinds of scientists. So scientists who will be able to think more broadly about the wider context of science. So it's seeing it as transformative, not just for individuals, but also for society. (Lecturer 4, University Two)

Values-based forms of intrinsic motivation were not mentioned in their discussions on intrinsic motivation by Ryan and Deci (2000a; 2000b). However, values pertaining to teaching as a force for social good feature prominently in the literature on teaching and motivation for teaching by writers in the field of higher education with a more socio-cultural perspective such as Rowland (2000) and Nixon (2001). Intrinsic sources of motivation were mentioned by more people at University Three than at the other two, since academics at University Three appeared to have a 
higher teaching load and conditions of poverty were more prominent in this geographic setting. This is conjecture, however, and would require further investigation, including research into the cultural influences on academics at each of the institutions.

\section{Extrinsic motivation}

Table 2: Forms of extrinsic motivation per institution

\begin{tabular}{|l|l|l|l|}
\hline \multicolumn{5}{|c|}{ Forms of extrinsic motivation } \\
\hline & $\begin{array}{l}\text { Recognition } \\
\text { according to number } \\
\text { of academics who } \\
\text { mentioned this }\end{array}$ & $\begin{array}{l}\text { Direct or indirect material } \\
\text { incentives } \\
\text { according to number of } \\
\text { academics who mentioned this }\end{array}$ & $\begin{array}{l}\text { Policy: persuasion or } \\
\text { coercion } \\
\text { according to number of } \\
\text { academics who mentioned this }\end{array}$ \\
\hline $\begin{array}{l}\text { University One } \\
11 \text { interviewed }\end{array}$ & 0 & 0 & 0 \\
\hline $\begin{array}{l}\text { University Two } \\
10 \text { interviewed }\end{array}$ & 1 & 0 & 0 \\
\hline $\begin{array}{l}\text { University Three } \\
10 \text { interviewed }\end{array}$ & 1 & 5 & 1 \\
\hline
\end{tabular}

Forms of extrinsic motivation that were cited included recognition for teaching achievements, direct or indirect material incentives, and persuasion or coercion via policy. Extrinsic motivation was mentioned less than intrinsic motivation across the three institutions, as can be seen in Table 2. Extrinsic motivation was mentioned by academics mostly at University Three, where there was a policy of compelling lecturers to do a short course on assessment, and where promotion criteria for doing so were spelt out. However, even at University Three, the academics mentioned this form of motivation in a more guarded manner. Two colleagues emphasised that although they were encouraged by extrinsic sources, these were combined with an intrinsic drive. One of the academics at University Three, when asked why she did the compulsory short course on assessment, responded:

I think a combination, of what was at the time a requirement. It was not pressure from anyone, but it was just an institutional requirement, which, in a way, served my purpose because I thought, look, I'm going into this, so I'd better get to know the ins-and-outs. So for me it was an institutional requirement that, in a way, intersected with what I thought was necessary. (Lecturer 10, University Three)

The response indicates the positive effect of congruence between institutional policy prescriptions and personal motivations, as noted in the study on academics' motivation at two UK universities by Crawford (2010).

At University Three interviewees said that although there were prescriptions to attend these courses at the institutional level, in many of the faculties these were not monitored and attendance was not encouraged. At best, there was a laissez-faire approach and individuals were 
not hindered from attending. There was also a suggestion that although promotion was tied to attendance of the various modules, many individuals were apathetic about promotion.

Although academics at all three institutions appeared to be motivated more by intrinsic than extrinsic measures when they were asked what would motivate others - thus, forms of extrinsic motivation evident via their absence - several more academics at Universities One and Two mentioned the importance of recognition or material benefits. Interestingly, none mentioned policy as persuasion or coercion. These responses suggest that extrinsic motivation is a factor, but a less common one amongst academics who are enthusiastic about improving their teaching. An academic at University One shared the sober and instrumental way she thought about material benefits in relation to her age and self-improvement, which, at her university, motivated her to focus on her research rather than her teaching, despite her love for teaching:

I use my research money more often to buy in replacement teachers to free me to do research than I would if there was more benefits attached to teaching for me. So there aren't those financial incentives .... It has to do also with my age, that I am in my 50s now, I am retiring in ten years' time. I was a foolish young person who didn't invest properly. I have not, I don't have a paid off house, so for me at this point in time financial incentives are very important. (Lecturer 2, University One)

Table 3: Forms of extrinsic motivation as absent

\begin{tabular}{|l|l|l|l|}
\hline \multicolumn{4}{|c|}{ Forms of extrinsic motivation as absent } \\
\hline & $\begin{array}{l}\text { Recognition } \\
\text { according to number } \\
\text { of academics who } \\
\text { mentioned this }\end{array}$ & $\begin{array}{l}\text { Direct or indirect material } \\
\text { benefits } \\
\text { according to number of } \\
\text { academics who mentioned this }\end{array}$ & $\begin{array}{l}\text { Policy: persuasion or } \\
\text { coercion } \\
\text { according to number of } \\
\text { academics who mentioned this }\end{array}$ \\
\hline $\begin{array}{l}\text { University One } \\
11 \text { interviewed }\end{array}$ & 3 & 3 & 0 \\
\hline $\begin{array}{l}\text { University Two } \\
10 \text { interviewed }\end{array}$ & 1 & 2 & 0 \\
\hline $\begin{array}{l}\text { University Three } \\
10 \text { interviewed }\end{array}$ & 0 & 2 & 0 \\
\hline
\end{tabular}

The interview data seems to suggest that for enthusiastic teachers, intrinsic motivation is more significant than extrinsic motivation. What is not clear from these interviews is whether extrinsic motivation might enhance the desire to learn to teach more if the sources of extrinsic motivation were more abundant. At Universities One and Two (University One in particular) there was not much evidence of extrinsic motivation.

Secondly, it is not clear what the impact of extrinsic motivation might have been on academics who are not enthusiastic about learning to teach. It is interesting that at University Two, retreats focusing on learning to teach were compulsory for deputy deans or heads of department. At University Three, short courses on learning to teach were compulsory for all 
academics. At both these institutions there were academics who had their first 'aha' moment when participating in these initiatives, as will be discussed in the next section. This suggests that if other conditions are favourable, coercion could be productive.

\section{Catalysing conditions}

Ryan and Deci (2000a) refer to social and environmental factors that facilitate or undermine intrinsic motivation as 'catalysing' conditions. In the data four sets of catalysing conditions were derived via content analysis: availability of opportunities to learn to teach, social relatedness, workload, and infrastructural and material support. These conditions appeared to be strongly tied to context.

Opportunities to learn to teach were both formal (events arranged by the universities' academic developers) and less formal (encounters with other academics in the department or faculty). Off-campus events were mentioned but not included in the analysis, as this is beyond the purview of the focus of the study on institutional context. Both types of opportunity, ie formal and informal were catalytic, in that they were able to trigger a learning trajectory that would last decades. In some instances the impact of the experiences was complementary, adding to what the academics had previously learnt. In other instances, the experiences were affirming of what the academics were doing. Lecturer 3 had already started paying attention to enhancing his teaching by the time an academic developer intervened directly:

And then I bumped into [academic developer] that joined us and I think that was my drive, in fact she motivated me to ... develop myself professionally. And she said that that would develop me as a teacher and then of course assist my students better. So we went for courses ..., staff development programmes, she invited me to go for conferences, told me I should start writing up. (Lecturer 3, University Two)

Many of the induction programmes, short courses and similar events hosted at all three universities were described as an 'eye-opener' and as extremely valuable. In the light of the debate about the relative significance of formal learning opportunities versus informal learning from colleagues in faculties (see arguments for the significance of learning in faculties by Knight, Tait and Yorke 2006), these interviews point to a synergy of both kinds of opportunities for learning, as the latter quote suggests. Both informal and formal learning opportunities have an important role to play in advancing professional learning.

Table 4: Learning opportunities 


\begin{tabular}{|l|l|l|}
\hline \multicolumn{3}{|c|}{ Formal and informal learning opportunities } \\
\hline & $\begin{array}{l}\text { Formal opportunities/Provided by TLC } \\
\text { according to number of academics who } \\
\text { mentioned this }\end{array}$ & $\begin{array}{l}\text { Informal opportunities } \\
\text { according to number of academics who } \\
\text { mentioned this }\end{array}$ \\
\hline $\begin{array}{l}\text { University One } \\
11 \text { interviewed }\end{array}$ & 3 & 4 \\
\hline $\begin{array}{l}\text { University Two } \\
10 \text { interviewed }\end{array}$ & 4 & 2 \\
\hline $\begin{array}{l}\text { University Three } \\
10 \text { interviewed }\end{array}$ & 6 & 1 \\
\hline
\end{tabular}

Table 4 suggests that informal opportunities to learn at University Three were very limited. In the light of this lack of opportunities to learn, in the tea-room or at seminars or faculty events, the role played by the Centre for Teaching and Learning becomes particularly significant.

Informal support for learning in the faculty, department or workgroup includes encouragement and moral support. Both informal learning opportunities and moral support from peers or more senior colleagues are derived from how colleagues relate to one another and influence each other in faculties, departments or workgroups. The teaching and learning microculture is described variously as the influence of 'teaching and learning regimes' in workgroups by Trowler and Cooper (2002), or the significance of learning via social networks by Roxå and Mårtensson (2009; 2015). The opportunities to learn and the moral support are discussed separately in this study, as the mode (providing opportunities to learn v. encouraging to learn) differs in each case.

Moral support for learning to teach was described in terms of deans or heads of departments encouraging academics to become engaged in professional development, or academics supporting each other via regular seminars or tearoom chats. The perceptions of the support and encouragement for learning to teach at the faculty, department or workgroup differed amongst colleagues at the three universities. Table 5 records the strongest level of support being received at University Two and the least at University Three. This was not only in terms of number of mentions, but also in terms of the vehemence and emotion with which comments were made: at University Two appreciation for camaraderie and joint learning was extremely strong, whilst at University Three comments suggested a level of alienation with regard to support and encouragement for teaching and learning. One of the academics at that university ascribed this lack of solidarity and engagement to the fact that their faculty was the product of the merging of three institutions.

Table 5: Moral support 


\begin{tabular}{|l|l|l|}
\hline \multicolumn{2}{|c|}{ Moral support } \\
\hline & $\begin{array}{l}\text { Support experienced } \\
\text { according to number of academics } \\
\text { who mentioned this }\end{array}$ & $\begin{array}{l}\text { Support experienced as inadequate } \\
\text { according to number of academics who } \\
\text { mentioned this }\end{array}$ \\
\hline $\begin{array}{l}\text { University One } \\
11 \text { interviewed }\end{array}$ & 2 & 3 \\
\hline $\begin{array}{l}\text { University Two } \\
10 \text { interviewed }\end{array}$ & 7 & 2 \\
\hline $\begin{array}{l}\text { University Three } \\
10 \text { interviewed }\end{array}$ & 5 & 6 \\
\hline
\end{tabular}

Despite the lack of camaraderie amongst colleagues at University Three, there was a strong networking element in one faculty, where the academic interviewed encouraged this himself. An ex-dean, he had the authority and freedom to set up several collegial events and appreciated learning with others:

And then of course also I do try to talk to the colleagues who worked on the PGD and I thought it would also be easier to follow with them, which is why I hope I can still do one or two more of those courses. (Lecturer 5, University Three)

The third cluster of contextual conditions mentioned by the academics included IT support, administrative services (for example for managing large classes) and the condition of lecture halls. The cluster featured more strongly as a negative condition due to its inadequacy at University Three, both in relation to the number of comments and to their emphatic nature.

Table 6: Material and infrastructural support

\begin{tabular}{|l|l|l|}
\hline \multicolumn{2}{|c|}{ Material and infrastructural support } \\
\hline & $\begin{array}{l}\text { Support noted } \\
\text { according to number of academics } \\
\text { who mentioned this }\end{array}$ & $\begin{array}{l}\text { Support inadequate } \\
\text { according to number of academics who } \\
\text { mentioned this }\end{array}$ \\
\hline $\begin{array}{l}\text { University One } \\
11 \text { interviewed }\end{array}$ & 1 & 0 \\
\hline $\begin{array}{l}\text { University Two } \\
10 \text { interviewed }\end{array}$ & 5 & 3 \\
\hline $\begin{array}{l}\text { University Three } \\
10 \text { interviewed }\end{array}$ & 1 & 5 \\
\hline
\end{tabular}

There were particularly sharp comments about the condition of lecture halls at University Three. The comment below demonstrates the length the lecturer went to in order to simply make her voice heard by students. The time she took was time potentially taken away from professional development:

I offer them extra lectures, you know, lecture-driven tutorials. In other words, tutorials that are run by the lecturer, as well as normal tutorials, because of the facilities, like the lecture venues that ... don't support a projector, I've actually done a workbook for students. ... if they can't see the board or they can't hear me, they've still got the notes in front of them. And ... because I have problems 
with voice projection in large classes, I end up circling the lecture venues, so that everybody can get to hear me at some point in time. ... I spend a lot of time making my notes and getting them printed and following up with ... the note making. I try to put them in a way that is easily understandable. I spend a lot of my time on that and if I had more, if I didn't have to really do all of that, in other word if students could see the board, ... I wouldn't have to give them as comprehensive notes and then I could actually spend time on research and my own professional development. (Lecturer 3, University Three)

This account demonstrates lack of material support as constraining the lecturer's professional development, rather than as demotivating her per se. The same distinction is relevant to the final 'catalysing' condition, workload. This condition was apparent at University Three not only from the comments of academics about what hinders their participation in professional development, but also from the accounts of their teaching responsibilities. According to the interviewees these were substantially heavier than the teaching responsibilities at Universities One and Two. The following comment from a lecturer who is passionate about her teaching was emphatic about workload, but more than this, it demonstrates the feelings of many of the interviewees at University Three that their extensive teaching loads impeded their professional development in relation to research and community interaction, as well as their development in relation to teaching more specifically:

[I] want somebody to share my teaching job. I can do, instead of four courses, let me do two courses. I would then be able to do research, community engagement and many other areas I would be able to do. ... Because I'm doing four courses, it would hinder the quality, but at the moment I'm trying my level best, but I'm not sleeping enough. My social life is affected, my personal life is affected. So the quality of my personal and social life has gone down in order to maintain the quality of teaching. (Lecturer 6, University Three)

Table 7: Workload

\begin{tabular}{|l|l|}
\hline \multicolumn{2}{|c|}{ Workload as a constraint } \\
\hline & $\begin{array}{l}\text { Noted } \\
\text { according to number of } \\
\text { academics who mentioned this }\end{array}$ \\
\hline $\begin{array}{l}\text { University One } \\
11 \text { interviewed }\end{array}$ & 1 \\
\hline $\begin{array}{l}\text { University Two } \\
10 \text { interviewed }\end{array}$ & 1 \\
\hline $\begin{array}{l}\text { University Three } \\
10 \text { interviewed }\end{array}$ & 7 \\
\hline
\end{tabular}

\section{DISCUSSION}

Observations arising out of these 31 interviews with academics can only be tentative, but they do suggest certain tendencies and possibilities that could be investigated further. For a group of 31 South African academics who were mostly very committed to their teaching, the intrinsic 
forms of motivation were more prominent than extrinsic forms. With regard to the conditions that 'catalyse' intrinsic motivation, it would seem that these conditions have an influence on sources of motivation that are both intrinsic as well as extrinsic. For example, at University Three, where policy dictated that everyone should do certain short courses for promotion, the policy was not fully adhered to, possibly because of the negative contextual conditions described above. Furthermore, contrary to Ryan and Deci’s (2000a) claim that studies have shown that extrinsic forms of motivation can remove the locus of control from individuals and negatively affect intrinsic motivation, several of the academics implied that extrinsic forms complemented their intrinsic motivation. Ryan and Deci's more general view (2000a; 2000b) that motivation is not unitary, but varied according to individual, context and target, is supported by the analysis of the data.

Whether the three psychological needs discussed by Ryan and Deci (2000a; 2000b), namely competence, relatedness and autonomy, inform the basis for motivation was not explored conclusively in this study. However it would seem that the various catalysing conditions relate, even if indirectly, to these needs. For example, the provision of opportunities to learn to teach should lead to an academic's sense of increased competence, and from there, to motivation. Resource constraints could cause a lecturer to feel less competent, as in the case of Lecturer 3 at University Three, and because of a feeling of lack of competence, a lecturer might easily become discouraged. Lecturer 3 did not become discouraged, but many others might have. The cost and energy to sustain motivation under these conditions is higher, as Archer (2000) would argue, on the subject of constraints and the greater expense that individuals have to go to in order to circumnavigate them. As discussed in the previous section, there was a range of conditions that pertained directly to a sense of relatedness, most notably that of moral support. One could argue that the third need, that of autonomy, is interrelated with competence and relatedness. For example, if one feels competent as a teacher, one might well feel more in control, and thus experience a sense of autonomy.

The interviews provide a distinct impression that contexts have a powerful and differentiating influence on motivation. The reasons why there were more examples of intrinsic motivation cited by lecturers at University Three, the most resource-constrained, were not explored, and could be taken further by future studies. Extrinsic forms of motivation were also cited more often at University Three, although this could be due to the fact that there were more policies advocating recognition of good teaching and compulsion with regard to attendance of short courses at University Three. At University Two the academics were much more enthusiastic about the social and learning support available in departments and faculties. In University Three, negative features such as workload and weak infrastructural and material 
support were most cited.

From the data it would seem as if contextual variations have to do with institutional particularities regarding support for teaching and learning (for example whether a set of short courses and diploma on teaching and learning is available or not, or how well the Centre for Teaching and Learning functions); socio-economic factors (workload and material provisioning); and university identity in relation to teaching focus.

With regard to the identity as a teaching institution, both Universities Two and Three had clearer policy positions regarding the importance of teaching than University One. Yet this positioning played itself out differently at Universities Two and Three.

The idea that the contextual differences are socio-economic and institutional identitybased (the latter pointing back to issues of history, politics and institutional differentiation, thus issues of power and privilege), implies the need to locate studies about the influence of context on motivation within a broader sociological and political context, rather than purely in a psychological paradigm. This study has provided a finer focus on the psychological, but strongly suggests that the psychological is very tightly interwoven with the social and material, and points to the need to locate discussions on professional academic development and learning to teach within broader debates about equity and transformation.

A point for further discussion is the status of the 'catalysing' conditions. Writing from within an industrial psychology paradigm, Herzberg (1968) describes factors that do not lead to motivation, but which in their absence demotivate, as 'hygiene factors'. Examples of hygiene factors in the workplace cited by Herzberg are work conditions or salaries. Some of the catalytic conditions described in this study are not merely demotivating: they constrain performance, competence and satisfaction, and indirectly lead to demotivation. The characterisation of such factors as systemic structural and cultural 'enablements' and 'constraints', as can be found in the social realist research of Margaret Archer (2000; 2007), might be a useful way of describing these catalytic conditions.

The study does not go so far as to consider the effect of extrinsic motivation on individuals who are not at all intrinsically motivated. This could be the basis for further study. The study does not examine in detail the influences of the different forms of extrinsic motivation, namely recognition and status, financial and material reward and compulsion. These differences could be investigated in more detail.

\section{IMPLICATIONS}

The purpose of this as a study - in the 'pragmatic' mode - was to consider the policy implications, at both the national and institutional level of the role of intrinsic and extrinsic 
motivation. In the study intrinsic motivation was found to be salient. However, this research sample is weighted in favour of intrinsically motivated lecturers. For intrinsically motivated lecturers extrinsic forms can be catalytic and complementary, but are not primary. The implication of this, and the precepts of self-determination theory that extrinsic motivation might displace autonomy, is that extrinsic forms such as material or status incentives should at all costs not displace sources of intrinsic motivation.

Ryan and Deci (2000b) maintain that there is little one can do to control individuals' intrinsic motivation, but that one can influence extrinsic motivation. This study suggests that forms of extrinsic motivation, for example policy directives or reward schemes may well be productive in encouraging academics to wish to learn to teach, and therefore should be encouraged. However, these forms are far more effective if they are accompanied by favourable social and material conditions. Extrinsic motivation seems to be heavily influenced by contextual conditions, whether these are more social, political or material. If national policy makers or university senior managers wish to influence academics' motivation to teach via extrinsic means such as policy on the recognition of good teaching or career pathing in relation to the teaching function, they should ensure that environmental conditions support these extrinsic measures. To put it idiomatically, a national teaching excellence scheme or a good training scheme might be a cherry on the cake - but the ingredients for the baking of the cake should still be there. This is a longer, deeper, more expensive but more sustainable endeavour. This is applicable at both institutional and national levels.

A final implication is that studies across institutions have an important role to play in teasing out the nature, meaning and relationships of concepts such as intrinsic and extrinsic motivation, in order to understand the significance of such constructs in relationship to the broader socio-political context where concerns for equity and social justice loom so large.

\section{ACKNOWLEDGEMENTS}

This study forms part of the Structure, Culture and Agency research project, with acknowledgement to the research team for the data collection and to the National Research Foundation for the research funding (grant number: 90353).

\section{REFERENCES}

Archer, M. 2000. Being human: The problem of agency. Cambridge: Cambridge University Press.

Archer, M. 2007. Making our way through the world: Human reflexivity and social mobility. Cambridge: Cambridge University Press.

Crawford, K. 2010. Influences on academics' approaches to development: Voices from below. International Journal for Academic Development 15(3): 189-202. 
Creswell, J. 2003. Research design: Qualitative, quantitative and mixed methods approaches. Thousand Oaks: Sage.

Greene, J., H. Kreider and E. Mayer. 2005. Combining qualitative and quantitative methods in social inquiry. In Research methods in the social sciences, ed. B. Somekh and C. Lewin, 274-282. London: Sage.

Herzberg, F. 1968. One more time: How do you motivate employees? Harvard Business Review 46(1): 53-62.

Kane, R., S. Sandretto and C. Heath. 2004. An investigation into excellent tertiary teaching: Emphasising reflective practice. Higher Education 47: 283-310.

Knight, P., J. Tait and M. Yorke. 2006. The professional learning of teachers in higher education. Studies in Higher Education 31(3): 319-339.

Leibowitz, B., S. van Schalkwyk, J. Ruiters, J. Farmer and H. Adendorff. 2012. 'It's been a wonderful life': Accounts of the interplay between structure and agency by 'good' university teachers'. Higher Education 63: 353-365.

Nixon, J. 2001. 'Not without dust and heat': The moral bases of the 'new' academic professionalism. British Journal of Educational Studies 49(2): 173-186

Roxå, T. and K. Mårtensson. 2009. Significant conversations and significant networks - Exploring the backstage of the teaching arena. Studies in Higher Education 34(5): 547-559.

Roxå, T. and K. Mårtensson. 2015. Microcultures and informal learning: A heuristic guiding analysis of conditions for informal learning in local higher education workplaces. International Journal for Academic Development 20(2): 193-205.

Rowland, S. 2000. The enquiring university teacher. Buckingham: SRHE and OUP.

Roziek, J. 2013. Pragmatism and post-qualitative futures. International Journal of Qualitative Studies in Education 26(6): 692-705.

Ryan, R. and E. Deci. 2000a. Self-determination theory and the facilitation of intrinsic motivation, social development and well-being. American Psychologist 55(1): 68-78.

Ryan, R. and E. Deci. 2000b. Intrinsic and extrinsic motivation: Classic definitions and new directions. Contemporary Educational Psychology 25: 54-67.

Trowler, P. 2012. Doing insider research in universities. Kindle Edition.

Trowler, P. and A. Cooper. 2002. Teaching and learning regimes: Implicit theories and recurrent practices in the enhancement of teaching and learning through educational development programmes. Higher Education Research \& Development 21(3): 221-230.

Webster-Wright, A. 2009. Reframing professional development through understanding authentic professional learning. Review of Educational Research 79(2): 702-739. 